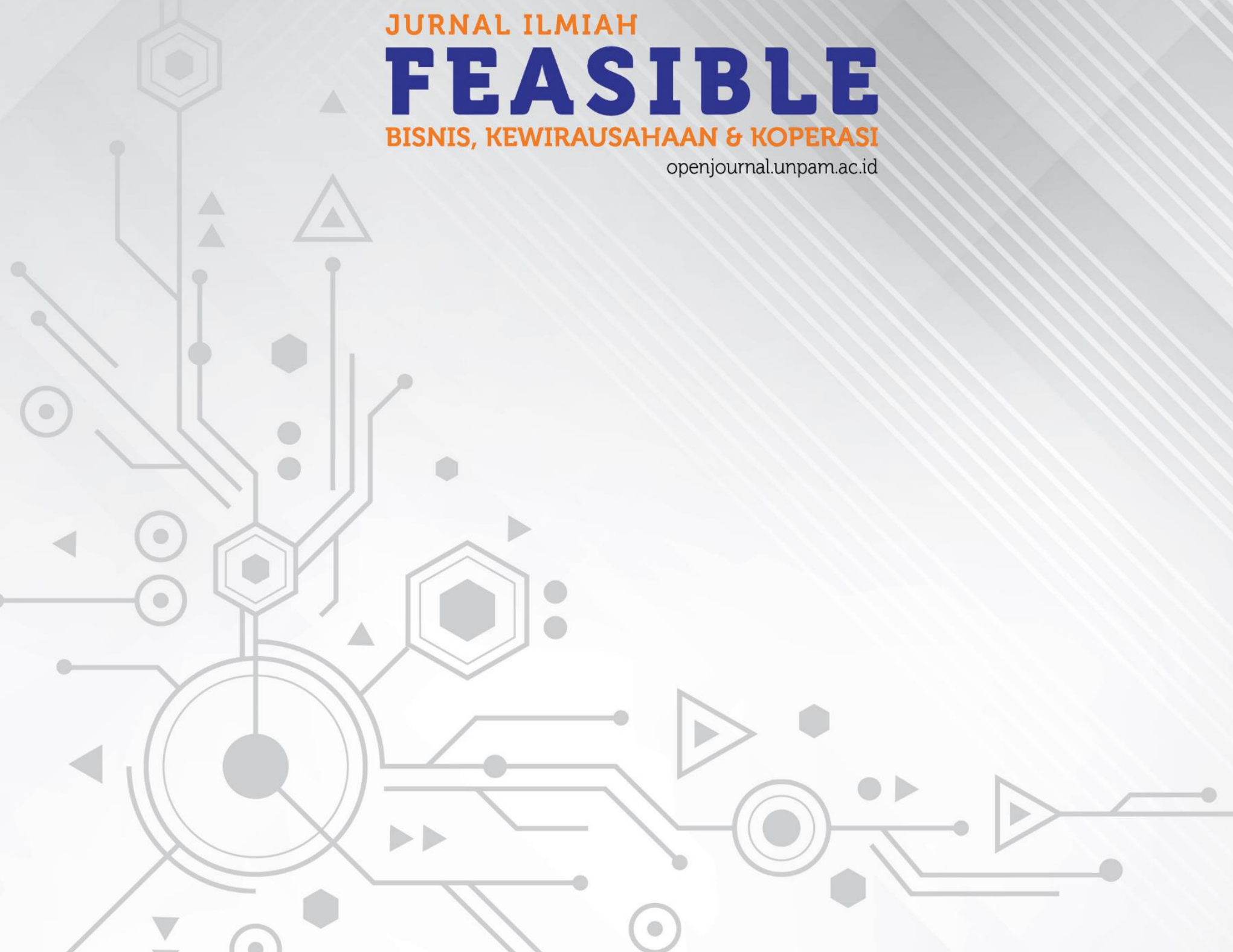




\title{
PENGARUH LIKUIDITAS DAN SOLVABILITAS TERHADAP RETURN SAHAM PADA PT. UNILEVER INDONESIA (PERSERO), TBK PERIODE 2011-2018
}

\author{
Gatot Kusjono' $^{1}$ Fegi Patricia Carolin² \\ Fakultas Ekonomi, Universitas Pamulang \\ doseno00434@unpam.ac.id, fegipatricia@gmail.com
}

\begin{abstract}
Abstrak
Tujuan penelitian ini untuk mengetahui pengaruh Likuiditas dan Solvabilitas terhadap Return Saham Perusahaan pada PT. Unilever Indonesia (Persero),Tbk yang terdaftar di BEI periode 2011-2018. Sifat penelitian ini kausalitas dengan pendekatan kualitatif yang akan menjelaskan hubungan sebab akibat antara variabel independent terhadap variabel dependennya. Analisis data yang digunakan meliputi: rasio keuangan dengan CR, DER, dan ROA, uji deskriptif, uji asumsi klasik, uji hipotesis dan uji regresi linier berganda. Hasl uji $t$ (parsial) diperoleh Current Ratio (CR) pengaruhnya tidak signifikan terhadap Return Saham (ROA), sedangkan Debt to Equity Ratio (DER) berpengaruh signifikan terhadap Return Saham. Hasil uji F (simultan), Current Ratio dan Debt to Equity Ratio berpengaruh secara signifikan terhadap Return Saham Perusahaan dengan konstribusi sebesar 92,0\%. Hal ini juga diperkuat dengan hasil nilai $F_{\text {hitung }}(28,799)>F_{\text {tabel }}(5,79)$ dan nilai signifikansi sebesar 0,002 .
\end{abstract}

Kata Kunci : Likuiditas, Solvabilitas, Current Ratio, Return On Asset, Return Saham

\begin{abstract}
The purpose of this study was to determine the effect of Liquidity and Solvency on Company Stock Returns at PT. Unilever Indonesia (Persero), Tbk, which was listed on the IDX for the period 2011-2018. The nature of this study is causality with a qualitative approach that will explain the causal relationship between the independent variables and the dependent variable. Analysis of the data used includes: financial ratios with $C R, D E R$, and ROA, descriptive test, classic assumption test, hypothesis test and multiple linear regression test. The t test (partial) obtained by Current Ratio (CR) has no significant effect on Stock Return (ROA), while Debt to Equity Ratio (DER) has a significant effect on Stock Return. F (simultaneous) test results, Current Ratio and Debt to Equity Ratio significantly influence the Company's Stock Return with a contribution of $92.0 \%$. This is also reinforced by the results of the value of Fcount (28.799)> Ftable (5.79) and a significance value of o.oo2.
\end{abstract}

Keywords: Liquidity, Solvency, Current Ratio, Return On Assets, Stock Return 
JURNAL ILMIAH FEASIBLE: Bisnis, Kewirausahaan \& Koperasi, Vol.2.No.1 Februari 2020: 1-10

\section{PENDAHULUAN}

\section{Latar Belakang}

Perusahaan didirikan dengan bertujuan untuk memperoleh laba yang merupakan kebutuhan perusahaan untuk membuktikan bahwa perusahaan itu benar-benar berkembang. Laba tersebut sangat diperlukan perusahaan sebagai tambahan pembiayaan dalam menjalankan usahanya dan untuk menjaga kemajuan perusahaan. Kinerja perusahaan yang baik akan berdampak kepada perolehan keuntungan atau laba yang baik pula.

Untuk menilai kinerja suatu perusahaan dapat diketahui dengan melihat analisis rasio keuangan yang meliputi tingkat likuiditas, tingkat profitabilitas dan nilai perusahaan. Sehingga akan diketahui kemampuan perusahaan dalam memenuhi kewajiban jangka pendek dan jangka panjangnya.

"Semakin baik kinerja keuangan suatu perusahaan pasti semakin baik pula nilai perusahaannya" (Triagustina.2014). Untuk menentukan nilai suatu perusahaan, salah satu faktor yang harus diperhatikan adalah faktor profitabilitas. Kemampuan perusahaan untuk memperoleh laba yang besar dan stabil akan meningkatkan kepercayaan para investor karena menunjukkan kinerja perusahaan yang tersusun dengan baik. Sehingga dengan kepercayaan tersebut nilai saham perusahaan juga akan naik. Dengan meningkatnya nilai saham perusahaan maka akan meningkatkan kepercayaan pemegang saham.
Menurut Soliha dan Taswan (2002), "profitabilitas adalah tingkat keuntungan bersih yang mampu diraih oleh perusahaan pada saat menjalankan operasinya. Profitabilitas perusahaan dapat dilihat melalui rasio-rasio profitabilitas seperti Return On Asset (ROA), Retrun On Equity (ROE), dan Return On Invesment (ROI)". Rasio profitabilitas sering digunakan untuk memprediksi harga saham atau return saham dengan mengukur efektifitas perusahaan dalam menghasilkan keuntungan dan memanfaatkan aktiva yang dimilikinya melalui ROA atau ROI.

Rasio likuiditas perusahaan mencerminkan tingkat kemampuan perusahaan dalam melunasi kewajiban jangka pendek. Dengan rasio likuiditas yang semakin meningkat menunjukkan bahwa perusahaan memiliki kemampuan untuk melunasi kewajiban jangka pendeknya dengan baik. Karena kondisi keuangan perusahaan sangat kuat.

Rasio solvabilitas keuangan perusahaan diasosiasikan dengan rasio Debt to Equity Ratio (DER). Menurut Helfert (1998), “DER adalah suatu upaya untuk memperlihatkan proporsi relatif dari pemberi pinjaman terhadap hak kepemilikan, dan digunakan sebagai ukuran peranan hutang. Studi empiris mengenai hubungan DER dengan return saham digambarkan sebagai hubungan yang signifikan terhadap nilai return saham". Hasil penelitian ini didukung oleh penelitian yang dilakukan oleh Natarsyah (2000) dan Sunarto (2001). Semakin tinggi DER menunjukkan semakin 
JURNAL ILMIAH FEASIBLE: Bisnis, Kewirausahaan \& Koperasi, Vol.2.No.1 Februari 2020: 1-10

besar ketergantungan perusahaan terhadap pihak luar sehingga tingkat resiko perusahaan semakin besar dalam memenuhi hutangnya, yaitu membayar pokok hutang ditambah dengan bunganya. Hal ini membawa dampak pada menurunnya harga saham dan return saham, sehingga investor tidak responsif terhadap informasi ini dalam pengambilan keputusan investasi pada saham.

\begin{tabular}{|c|c|c|c|}
\hline \multicolumn{4}{|c|}{ Tabel 1.1 } \\
Rata-Rata Current Ratio, Debt To \\
Equity, Dan Return On Assets \\
PT. Unilever Indonesia, Tbk periode \\
20o8-2017. \\
\hline Tahun & CR(\%) & DER(\%) & $\begin{array}{c}\text { Return } \\
\text { Saham }\end{array}$ \\
\hline 2011 & 68.39 & 184.77 & 39.73 \\
\hline 2012 & 66.83 & 202.01 & 40.38 \\
\hline 2013 & 69.64 & 213.73 & 40.10 \\
\hline 2014 & 71.49 & 210.53 & 40.18 \\
\hline 2015 & 65.40 & 225.85 & 37.20 \\
\hline 2016 & 60.56 & 255.97 & 38.16 \\
\hline 2017 & 63.37 & 265.46 & 37.05 \\
\hline 2018 & 74.77 & 61.18 & 46.66 \\
\hline
\end{tabular}

Sumber: Laporan keuangan PT. Unilever Indonesia (persero), Tbk periode 20112018.

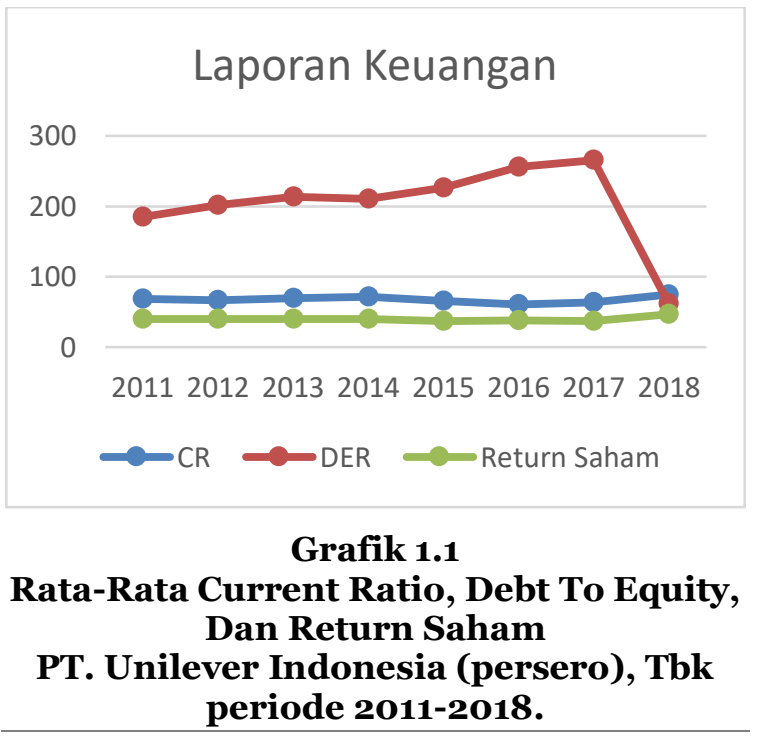

Pada gambar grafik 1.1 diatas dapat dilihat bahwa Current Ratio mengalami fluktuasi selama 8 tahun terakhir. Pada tahun 2011 Current Ratio sebesar 68.39\% di tahun berikutnya Current Ratio mengalami penurunan menjadi $66.83 \%$ dan di tahun berikutnya meningkat kembali menjadi 71.49 \% namun mengalami penurunan secara bertahap di 3 tahun terakhir paling rendah Current Ratio sebesar $63.37 \%$.

Pada gambar grafik 1.1 diatas Debt to Equity Ratio pada tahun 2011 sebesar 184.77 \% di setiap tahunnya Debt to Equity Ratio mengalami peningkatan secara signifikan namun di tahun 2018 mengalami penurunan yaitu Debt to Equity Ratio sebesar $61.18 \%$.

Pada gambar grafik 1.1 Return Saham mengalami fluktuasi selama 8 tahun terakhir. Pada tahun 2011 sebesar $39.73 \%$, di tahun 2012 meningkat kembali sebesar $40.38 \%$ dan di 5 tahun berikutnya mengalami penurunan secara bertahap, namun di tahun 2018m3ngalami peningkatan yaitu Return Saham sebesar $46.66 \%$.

Berdasarkan latar belakang di atas, maka rumusan masalah pada penelitian ini apakah likuiditas (CR) dan dan solvabilitas (DER) berpengaruh terhadap return saham (ROA) dan penelitian ini bertujuan untuk mengetahui:

1. Pengaruh pengaruh likuiditas terhadap return saham pada PT. Unilever Indonesia (Persero), Tbk periode 20112018. 
2. Pengaruh pengaruh solvabilitas terhadap return saham pada PT. Unilever Indonesia (Persero), Tbk periode 2011-2018.

3. Pengaruh pengaruh likuiditas dan solvabilitas terhadap return saham pada PT. Unilever Indonesia (Persero), Tbk periode 2011-2018.

\section{Kajian Literatur}

\section{Rasio Likuiditas}

Menurut Kasmir (2011:130) mengatakan bahwa "likuiditas yaitu seberapa likuid suatu perusahaan dalam memenuhi kewajiban jangka pendeknya saat ditagih".

\section{Rasio Solvabiltas}

Menurut Kasmir (2011:151) mengatakan bahwa "solvabilitas atau leverage ratio merupakan rasio yang digunakan untuk mengukur sejauh mana aktiva perusahaan dibiayai dengan hutang”. Artinya berapa besar beban utang yang ditanggung perusahaan dibandingkan dengan aktivanya.

\section{Rasio Profitabilitas}

Menurut Munawir (2012:70) "profitabilitas adalah rasio keuntungan atau rasio profitabilitas yaitu rasio yang menunjukkan kemampuan perusahan dalam mencetak laba. Untuk para pemegang saham, rasio ini menunjukkan tingkat penghasilan mereka dalam berinvestasi”.

\section{Return Saham}

Menurut Corrado dan Jodan (2000:5) "return saham adalah keuntungan yang diperoleh dari kepemilikan saham investor atas investasi yang dilakukannya, yang terdiri dari deviden dan capital gain atau loss”. Menurut Jogiyanto (2009:199) "return merupakan hasil yang diperoleh dari investasi”.

\section{Sistematika Penelitian}

Kerangka berfikir penelitian ditunjukkan dalam gambar 1.1.

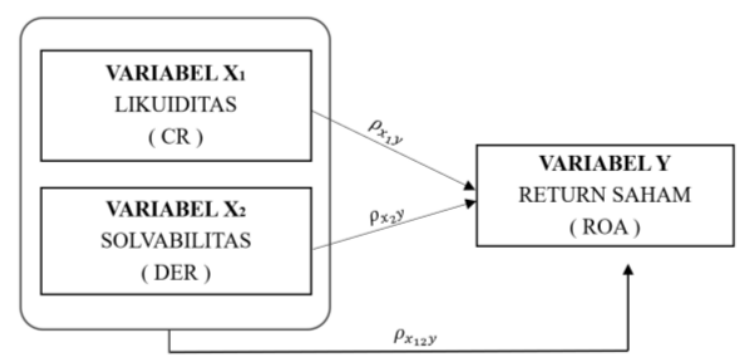

Gambar 1.1. Sistematika Penelitian

Keterangan:

$\rho_{\mathrm{x} 1 \mathrm{y}}=$ Pengaruh likuiditas (CR) terhadap Return Saham (ROA).

$\rho_{\mathrm{x} 2 \mathrm{y}}=$ Pengaruh solvabilitas (DER) terhadap Return Saham (ROA).

$\rho_{\mathrm{x} 12 \mathrm{y}}=$ Pengaruh likuidits (CR) dan solvabilitas (DER) terhadap Return Saham (ROA).

\section{Penelitian Terdahulu}

1. Penelitian yang dilakukan oleh Ahmad Agus Yasin Fadli (2018), mengenai Pengaruh Sumber Dana Pihak ketiga dan Current Ratio terhadap ROA pada PT Bank Negara Indonesia. Dari hasil penelitian sumber dana pihak ketiga dan CR berpengaruh terhadap ROA baik secara simultan maupun parsial. 
2. Penelitian yang dilakukan oleh Rian Sofiani, Dedi Hariyanto dan Heni Safitri (2018), mengenai Pengaruh TATO, FATO, DAR dan DER terhadap ROA pada Indek IDX30 yang terdaftar di Bursa Efek Indonesia. Dari hasil penelitian secara parsial TATO berpengaruh signifikan terhadap ROA, sedangkan FATO, DAR dan DER tidak berpengaruh terhadap ROA.

3. Penelitian yang dilakukan oleh Mahardhika P.A. dan Dohar Marbun (2016), mengenai Pengaruh Current Ratio dan Dept to Equity Ratio terhadap ROA. Dari hasil penelitian CR dan DER berpengaruh signifikan terhadap ROA.

\section{METODE}

Metode penelitian yang digunakan bersifat kasualitas dengan pendekatan deskriptif kuantitatif, yaitu melakukan pembahasan atas permasalahan yang dihadapi oleh perusahaan. Data yang dikumpulkan merupakan data skunder, berupa laporan keuangan PT. Unilever Indonesia (persero), Tbk. mulai tahun 2007 sampai dengan tahun 2017, yang sudah dipublikasikan pada situs resmi perusahaan dan www.idx.co.id.

Analisis data dilakukan dengan cara mengelompokkan data berdasarkan variabel dan jenisnya, membuat tabulasi data, menyajikan data, melakukan perhitungan data menggunakan program SPSS dan melakukan Analisa hasil untuk menjawab permasalahan menguji hipotesa yang diajukan.

\section{Tempat Penelitian}

Penelitian ini dilakukan pada PT. Unilever Indonesia (Persero), Tbk yang terdaftar pada BEI periode 2011-2018.

\section{Populasi dan Sampel}

Populasi yang digunakan yaitu keseluruhan laporan keuangan dari mulai PT. Unilever Indonesia (Persero) Tbk. Adapun sampel yang dipakai adalah laporan keuangan PT. Unilever Indonesia (persero), Tbk. mulai 2011 sampai dengan tahun 2018.

\section{HASIL dan PEMBAHASAN \\ Hasil}

\section{Uji Statistik Deskriptif}

Statistik deskriptif merupakan sebuah metode untuk mengetahui gambaran sekilas dari sebuah data. Berikut adalah hasil uji deskriptif data:

Tabel 1.2 Hasil Uji Statistik Deskriptif

\begin{tabular}{|l|r|r|r|} 
& \multicolumn{1}{|c|}{ Mean } & \multicolumn{1}{|c|}{$\begin{array}{c}\text { Std. } \\
\text { Deviation }\end{array}$} & \multicolumn{1}{|c|}{ N } \\
\hline RETURN & 39.9300 & 3.03556 & 8 \\
SAHAM & & 4.53877 & 8 \\
CR & 67.5488 & 85.32500 & 8 \\
DER & 214.4887 & 35.3 & \\
\hline
\end{tabular}

a. Dependent Variable: ROA

Dari tabel di atas variabel Likuiditas (CR) nilai rata-ratanya 67.5488 dan std. deviasi 4.53877. Variabel Leverage (DER) memiliki nilai rata-rata 214.4887 dan std. deviasi 35.32500. Sedangkan variabel Return Saham (ROA) memiliki nilai ratarata 39.9300 dan std. deviasi 3.03556 


\section{Uji Asumsi Klasik}

\section{Uji Normalitas}

Uji normalitas dilakukan dengan dengan melihat penyebaran data (titik) pada sumbu diagonal dari grafik. Data dikatakan normal apabila titik-titik data menyebar di sekitar garis diagonal.

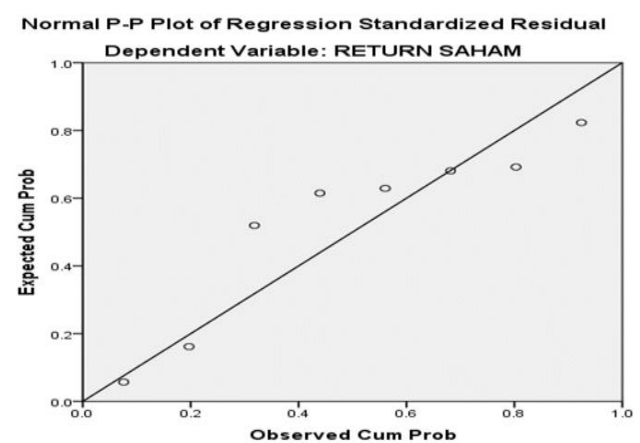

Gambar 1.2. Gambar normat P-P Plot Berdasarkan grafik di atas, data memenuhi asumsi normalitas, karena seluruh titik-titik datanya menyebar di sekitar garis diagonal.

\section{Uji Multikolinearitas}

Uji Multikolinearitas bertujuan untuk mengetahui apakah dalam model regresi ada interkorelasi atau kolinieritas antara variabel bebasnya. Interkorelasi antar variabel bebas dapat diketahui dengan melihat nilai VIF (Variance Inflacton Factor) yang lebih besar dari 10 dan nilai Tolerance yang kurang dari o,o1.

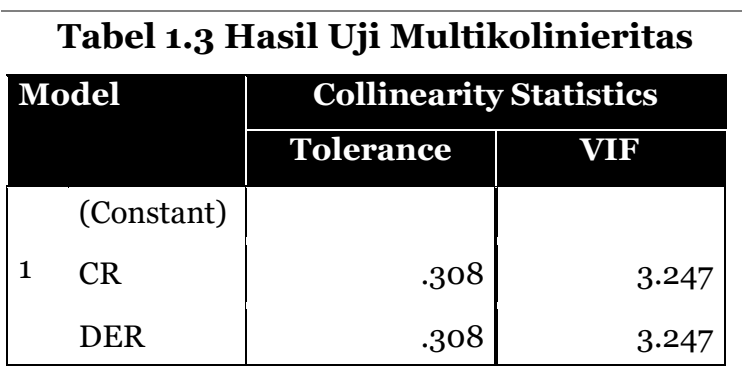

Hasil Uji Multikolinearitas tabel di atas diperoleh nilai VIF dari CR dan DER nilai $3.247<10$ ). Sedangkan nilai tolerance
0,308 lebih besar dari o,01, berarti tidak terjadi multikoliniearitas.

\section{Uji Heteroskedastisitas}

Uji heteroskedastisitas digunakan untuk mengetahui adanya ketidaksamaan varian dari residual untuk semua pengamatan pada model regresinya. Pengujian ini dengan melihat pola grafik regresi. Jika pada grafik ada pola tertentu berupa titiktitik yang membentuk suatu pola tertentu yang teratur dalam arti bergelombang, melebar kemudian menyempit, maka model regresi mengalami heteroskedastisitas.

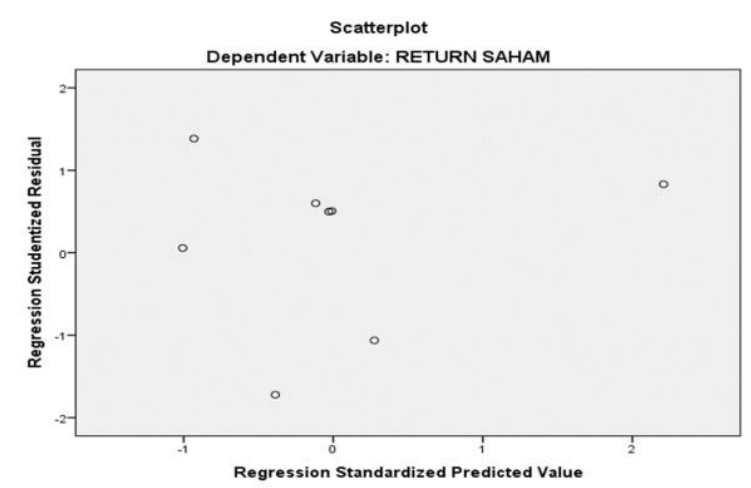

\section{Gambar 1.3. Uji Heteroskedastiisitas}

Hasil uji Heteroskedastisitas pada gambar 1.3, diperoleh titik-titik data menyebar dan tidak membentuk pola tertentu. Artinya model regresi bebas dari heteroskedastisitas.

\section{Uji Autokolerasi}

Uji autokorelasi digunakan untuk menguji apakah antar residual terdapat korelasi yang tinggi atau tidak. Pengujian autokorelasi menggunakan uji run test. Model dikatakan mengalami autokorelasi apabila nilai signifikansi residual hasil uji run test lebih besar dari 0,05 . 
JURNAL ILMIAH FEASIBLE: Bisnis, Kewirausahaan \& Koperasi, Vol.2.No.1 Februari 2020: 1-10

Tabel 1.4 Hasil Uji Autokorelasi

Runs Test

\begin{tabular}{|l|r|}
\multicolumn{2}{|c|}{ Runs Test } \\
\hline Test Value & $\begin{array}{c}\text { Unstandardized } \\
\text { Residual }\end{array}$ \\
Cases < Test Value & $\cdot 31527$ \\
Cases > = Test Value & 4 \\
Total Cases & 4 \\
\hline Number of Runs & 8 \\
Z & 5 \\
Asymp. Sig. (2-tailed) & .000 \\
\hline
\end{tabular}

Berdasarkan tabel di atas, diperoleh nilai Asymp. Sig (2-tailed) lebih besar dari 0.05 (1.00 > 0.05), berarti pada model tidak terjadi autokorelasi.

\section{Hasil Analisis Data}

\section{Uji Regresi Linear Berganda}

Uji regresi linier berganda digunakan untuk mengetahui pengaruh variabel bebas (CR dan DER) terhadap variable terikatnya (ROA). Hasil pengolahan data ditunjukkan pada tabel berikut:

Tabel 1.5 Hasil Regresi Linier Berganda
\begin{tabular}{|l|r|r|r|}
\hline Model & $\begin{array}{c}\text { Unstandardized } \\
\text { Coefficients }\end{array}$ & \multicolumn{1}{c|}{$\mathrm{t}$} & Sig. \\
\hline (Constant) & 44.096 & 3.613 & .015 \\
1 CR & .065 & .426 & .688 \\
DER & -.042 & -3.851 & .012 \\
\hline
\end{tabular}

Dari tabel di atas diperoleh persamaan regresi linier berganda sebagai berikut:

ROA $=44.096+0.065 C R-0.042 D E R$ $+\mathbf{e}$

1. Nilai Kkonstanta 44.096 menunjukan angka positif dapat diartikan dengan adanya Current Ratio (CR) Debt to Equity Ratio (DER) memiliki nilai konstan maka tingkat Return Saham perusahaan yang diproksikan oleh (ROA) sebesar 44.096.
2. Koefisien Current Ratio (CR) bernilai positif yaitu 0.065 artinya bahwa setiap kenaikan 1\% (CR) maka Return Saham yang di proksikan dengan ROA akan mengalami kenaikkan sebesar 0.065 dengan asumsi bahwa variabel bebas yang lain dari model regresi adalah tetap atau tidak mengalami perubahan.

3. Nilai koefisien Debt to Equity Ratio (DER) sebesar negatif 0.042. Apabila DER mengalami kenaikan 1\% maka Return Saham (ROA) akan mengalami penurunan sebesar 0.042 dengan asumsi variabel bebas lainnya dari model regresi tetap atau tidak mengalami perubahan.

\section{Uji F (Simultan)}

Uji sumultan (Uji F) digunakan untuk mengetahui apakah model regresi yang diperoleh sudah layak atau tidak untuk digunakan. Model regresi dikatakan layak apabila nilai $F_{\text {hitung }}$ lebih besar dari $F_{\text {tabel }}$ dan signifikansinya kurang dari 0,05. Berikut ini output hasil Uji F:

Tabel 1.6 Hasil Uji Simultan

\begin{tabular}{|c|c|}
\hline Fhitung & Signifikansi \\
\hline 28.799 & 0.002 \\
\hline
\end{tabular}

Hasil uji simutan (Uji F) antara variabel CR dan DER terhadap ROA diperoleh nilai $F_{\text {hitung }} \quad$ (28.799) $>F_{\text {tabel }}$ (5.79) dan nilai signifikan $0.002<0,05$. Artinya secara simultan variabel independen (CR) dan (DER) berpengaruh signifikan terhadap variabel dependen Return Saham (ROA). 
JURNAL ILMIAH FEASIBLE: Bisnis, Kewirausahaan \& Koperasi, Vol.2.No.1 Februari 2020: 1-10

\section{Hasil Uji t (Parsial)}

Uji $\mathrm{t}$ digunakan untuk mengetahui pengaruh variabel bebas secara terpisah (CR dan DER) terhadap variabel terikat (ROA).

\begin{tabular}{|c|r|r|c|c|}
\multicolumn{5}{c}{ Tabel 1.7 Hasil Uji Parsial } \\
\begin{tabular}{|c|r|r|c|} 
Variabel \\
Bebas
\end{tabular} & $t_{\text {hitung }}$ & Sig. & Ho & Ha \\
\hline CR & .426 & .688 & Diterima & Ditolak \\
DER & -3.851 & .012 & Ditolak & Diterima \\
\hline
\end{tabular}

Berdasarkan tabel di atas:

1) Nilai koefisien variabel Current Ratio sebesar $t_{\text {hitung }}(0.426)<t_{\text {tabel }}(0.426)$ dan nilai signifikan $0.688>0.05$. Sehingga Ho diterima dan Ha ditolak, Current Ratio tidak berpengaruh terhadap Return Saham (ROA) Perusahaan pada PT. Unilever Indonesia (Persero) Tbk periode 2011-2018.

2) Nilai koefisien variabel Debt to Equity Ratio (DER) sebesar $t_{\text {hitung }}(3.851)>t_{\text {tabel }}$ (3.613) dan nilai signifikan sebesar 0.012 $<$ 0.05). Sehingga Ho ditolak dan Ha diterima, artinya, DER berpengaruh signifikan terhadap Return Saham (ROA) Perusahaan pada PT. Unilever Indonesia (persero) Tbk periode 20112018.

\section{Koefisien Korelasi dan Determinasi}

Koefisien korelasi digunakan untuk mengetahui tingkat hubungan CR dan DER terhadap ROA. Sedangkan koefisien determinasi digunakan untuk mengetahui besarnya konstribusi variabel CR dan DER
Tabel 4.8 Hasil Koefisien Korelasi

\begin{tabular}{|c|c|}
\hline $\begin{array}{c}\text { Koefisien Korelasi } \\
(\mathbf{R})\end{array}$ & $\begin{array}{c}\text { Koefisien } \\
\text { Determinasi (R²) }\end{array}$ \\
\hline 0,959 & 0,92 \\
\hline
\end{tabular}

Berdasarkan tabel, nilai koefisien korelasi (R) sebesar 0.959, menunjukkan tingkat hubungan yang sangat kuat. Sedangkan nilai koesien determinasi sebesar $\mathrm{R}_{2}=0,92$ menunjukkan konstribusi Current Ratio (CR) dan Debt to Equity Ratio (DER) terhadap Return On Asset (ROA) sebesar $92.0 \%$.

\section{Pembahasan}

1. Pengaruh Likuiditas (CR) terhadap Return Saham (ROA)

Hasil uji parsial Likuiditas (CR) tidak berpengaruh terhadap Return Saham (ROA) dengan thitung $(0.426)<$ $t_{\text {tabel }}$ (0.426), dengan nilai signifikan sebesar $0.688>0.05$. Hasil penelitian ini tidak sejalan dengan Ahmad Agus Yasin Fadli (2018) bahwa CR berpengaruh terhadap ROA.

\section{Pengaruh Solvabilitas (DER) terhadap Return Saham (ROA)}

Hasil uji parsial solvabilitas (DER) berpengaruh signifkan terhadap Return Saham (ROA) dengan $t_{\text {hitung }}$ (3.851) > $t_{\text {tabel }}$ (3.613) dan nilai signifikan sebesar $0.012<0.05)$. Hasil penelitian ini tidak sejalan dengan Rian Sofiani, Dedi Hariyanto dan Heni Safitri (2018) bahwa DER berpengaruh terhadap ROA. 
JURNAL ILMIAH FEASIBLE: Bisnis, Kewirausahaan \& Koperasi, Vol.2.No.1 Februari 2020: 1-10

3. Pengaruh Likuiditas (CR) dan Solvabilitas (DER) terhadap Return Saham (ROA)

Hasil uji simultan CR dan DER berpengaruh signifikan terhadap Return Saham (ROA) dengan nilai $F_{\text {hitung }}$ (28.799) $>\mathrm{F}_{\text {tabel }}$ (5.79) dan nilai signifikan 0,002 < 0,05. Hasil penelitian ini sejalan Mahardhika P.A. dan Dohar Marbun (2016) bahwa Current Ratio dan Dept to Equity Ratio berpengaruh terhadap ROA.

\section{SIMPULAN}

\section{Kesimpulan}

1. Likuiditas yang diproksikan oleh Current Ratio (CR) tidak berpengaruh terhadap Return Saham yang diproksikan oleh Return On Asset (ROA) dengan nilai $t_{\text {hitung }}$ sebesar 0,426 dan signifikan $0.688>0.05$ ).

2. Solvabilitas yang diproksikan oleh Debt to Equity Ratio (DER) berpengaruh terhadap Return Saham yang diproksikan oleh Return On Asset (ROA) dengan nilai $t_{\text {hitung }}$ sebesar 3.851 dan signifikan 0.012<0.05).

3. Secara simultan CR dan DER berpengaruh signifikan terhadap ROA. Terbukti dengan hasil $F_{\text {hitung }}$ (28.799) > $\mathrm{F}_{\text {tabel }}(5 \cdot 79)$ dan signifikan 0,002<0,05. Pengaruhnya ditunjukkan oleh persamaan regresi linier $\mathrm{ROA}=44.096$ + o.065CR - 0.042DER + e dengan konstribusi sebesar 92,0.

\section{Saran}

1. Penelitian selanjutnya sebaiknya memakai jumlah sampel yang terbaru dan veriabel yang lain sehingga memungkinkan bisa mendapatkan kondisi perusahaan yang sebenarnya.

2. Perlu dicari variabel lain yang masih jarang diteliti sebagai variabel yang diduga mempengaruhi return saham.

3. Investor dalam melakukan pembelian saham perusahaan hendaknya dapat membaca kinerja keungan perusahaan diinterpretasikan dalam rasio-rasio keuangan.

\section{DAFTAR PUSTAKA}

Agustina dan Fitri Sumartio. 2014. Analisis Faktor-Faktor Yan Mempengaruhi Pergerakan Harga Saham Pada Perusahaan Pertambangan. Jurnal Wira Ekonomi Mikrosil Vol.4, No. 01 .

Arikunto, Suharsimi. 2006. Prosedur Penelitian Suatu Pendekatan Praktik. Jakarta: Rineka Cipta.

Fahmi, Irham 2011. Analisis Laporan Keuangan. Bandung: Alfabeta.

Fahmi, Irham 2012. Analisis Laporan Keuangan. Bandung: Alfabeta.

Fadli, A. Y. (2019). "Pengaruh Sumber Dana Pihak Ketiga Dan Current Ratio Terhadap Return On Assets (Roa) Pada PT Bank Negara Indonesia, Tbk.”. Tahun 20092016. Jurnal Semarak, Vol.1, No.3, hal 78-87. 
JURNAL ILMIAH FEASIBLE: Bisnis, Kewirausahaan \& Koperasi, Vol.2.No.1 Februari 2020: 1-10

Fahmi, (2012), “Analisis Kinerja Keuangan

(Panduan bagi Akademisi, Manajer

dan Investor untuk menilai dan menganalisis bisnis dari aspek keuangan)”, Penerbit: Alfabeta, Bandung.

Ghozali Imam.2011.”Aplikasi Analisis

Multivariate dengan Program

SPSS”. Edisi Kelima. Badan Penerbit Undip. Semarang.

Jogiyanto, Teori Portofolio dan Analisis Investasi, Edisi Keenam, Cetakan Pertama, BPF,. Yogyakarta, 2009. Jogiyanto, Teori Portofolio dan Analisis Investasi, Edisi Keenam, Cetakan Pertama, BPF,. Yogyakarta, 2009.

Kasmir. 2012 "Analisis Laporan Keuangan”. Raja Grafindo Persada Jakarta:2012.

Kasmir. 2014. "Analisis Laporan

Keuangan”. PT. Rajagrafindo Persada: Jakarta

Mahardhika, P. A., \& Marbun, D. (2016). "Pengaruh Current Ratio Dan Debt To Equity Ratio Terhadap Return On Assets". Widyakala: Journal of Pembangunan Jaya University, 3, 23-28.

Munawir, 2002, Analisis Laporan Keuangan, Liberty, Yogyakarta.

Munawir, 2012, Analisis Laporan Keuangan, Edisi 4, Yogyakarta, Liberty.

Sofiani, R., Hariyanto, D., \& Safitri, H. (2018). Pengaruh TATO, FATO, DAR, dan DER Terhadap ROA pada
Indeks IDX30 yang Terdaftar di Bursa Efek Indonesia. Jurnal Produktivitas: Jurnal Fakultas Ekonomi Universitas Muhammadiyah Pontianak, 5(1).

Soliha, E., dan Taswan. 2002. "Pengaruh Kebijakan Hutang Terhadap Nilai Perusahaan Serta Beberapa Faktor Yang Mempengaruhinya.

Sugiyono."Metode Penelitian Kuantitatif, Kualitatif dan $R \& D ”$. Alfabeta. Bandung:2009

Sugiyono_2014."Metode Penelitian Kuantitatif, Kualitatif dan $R$ \& $D$ ”. Alfabeta. Bandung.

Sofiani, R., Hariyanto, D., \& Safitri, H. (2018). Pengaruh TATO, FATO, DAR, dan DER Terhadap ROA pada Indeks IDX30 yang Terdaftar di Bursa Efek Indonesia. Jurnal Produktivitas: Jurnal Fakultas Ekonomi Universitas Muhammadiyah Pontianak, 5(1). 